\title{
Education, Policy, and Juvenile Delinquents: A Mixed Methods Investigation During COVID-19
}

\author{
David C. Coker ${ }^{1}$ \\ ${ }^{1}$ Department of Advanced Education Program, Fort Hays State University, Hays, Kansas, USA \\ Correspondence: David Coker, Department of Advanced Education Program, Fort Hays State University, Hays, \\ KS, USA. E-mail: dccoker@fhsu.edu
}

Received: November 21, 2020 Accepted: December 23, 2020 Online Published: December 30, 2020

doi:10.5539/jel.v10n1p22 URL: https://doi.org/10.5539/jel.v10n1p22

\begin{abstract}
COVID-19 mitigation efforts resulted in many schools making the transition to online and remote instruction. Juvenile delinquents, as a group, attained lower academic achievement before the pandemic, and little was known how juvenile delinquents' education fared after schools ceased face-to-face instruction. Using a mixed methods approach, three steps were conducted to analyze the education of juvenile delinquents in the United States: a qualitative literature review, a grounded theory study of teachers' concerns in traditional schools, and an instrumental case study of juvenile delinquents' enrollment during COVID-19. Researchers and experts recommended the development of a community online and in remote instruction, but most teachers felt overwhelmed and unable to rise to the challenge. Juvenile delinquents responded by most students disappearing from school attendance rolls. A grand theme, to shift the nature of online learning, is offered based upon the convergence of the research findings. A theory of humanistic schooling online, centered on a community of learners with the dimensions of academics, physical health, social, and attention to the individual, offers to radically transform practices and past recommendations.
\end{abstract}

Keywords: COVID-19, juvenile delinquents, educational policy, online learning, mixed methods research

\section{Introduction}

In March 2020, due to COVID-19, school districts across the nation made the decision to close schools and move to remote learning. What happened was many schools shuttered their doors, sent everyone home, and instructed stakeholders to implement a model on the fringe of public education-online and remote instruction. Students were already unengaged (Fullan, 2013), but there strong evidence revealed students did not log in to classes and the ones who did, did little (Graham, 2020). As found in national surveys and research, remote learning has been a poor replacement for in-person learning (Hobbs \& Hawkins, 2020; Wexler, 2019a).

Juvenile delinquents were a population most at risk. There were approximately 50,000 students incarcerated in the United States on any given day (Sedlak \& Bruce, 2016). There was little research on the effectiveness of technology in education (Cuban \& Jandrić, 2015; García Mathewson \& Butrymowicz, 2020), and no known research was located which directly dealt with students who ended up incarcerated in juvenile detention centers. How at-risk students responded to remote instruction was an important problem, and understanding how juvenile delinquents participated in the post-COVID school could help policy makers improve outcomes for all students. The goal of the study was the following: How can schools improve instruction for juvenile delinquents and all students to increase student achievement and persistence?

The study was broken down into four sections. There was a literature review of practices during COVID-19 and the characteristics of juvenile delinquency. The case study used a mixed methods approach. First there was a qualitative literature review to describe education policy in the United States for effective instruction in the transition from in-person to online and remote learning. Next, there was a grounded theory study of what teachers in the United States thought about teaching online and remotely during the pandemic. Finally, an instrumental case study of juvenile delinquents in the United States gave an analysis of students and their experiences. After the results, there is a discussion with recommendations. The study ended with a conclusion and questions for future research. 


\section{Literature Review}

There was ample evidence remote and online learning, since school closures from COVID-19 in March 2020, have been a spectacular failure and could lead to a large loss in learning for a child's entire schooling experience (Hobbs \& Hawkins, 2020; Kaffenberger, 2020). Schools across the Unites States have students who were unengaged, with many students on average spending $90 \%$ or less time in school than pre-COVID-19 (Brenan, 2020; Jacobson, 2020). Organizations, such as the International Society for Technology in Education (ISTE), stated schools need to move technology from a concern for activities and budgetary concerns to a focus on improving student learning (Klein, 2019). Despite the challenges of remote learning, findings suggested most research was neither rigorous nor methodologically sound (Byun \& Joung, 2018).

Suggestions for improving remote learning were many. Coker (2020b), in a qualitative literature review and case study, suggested there could be four drivers to improve remote and online learning: collaboration, efficiency, research-based instruction, and expectations. Colleges and public schools have found for decades online and remote learning resulted in markedly lowered academic achievement (Bettinger \& Loeb, 2017; Wexler, 2019a). Research and data-driven instruction were key themes, but teachers neither have the skills nor time to translate findings and local data into actionable classroom instruction (Gleason et al., 2019; Neuman, 2016). There was a need to upset the system and transform collaboration, with the key metric being the evaluation of the end user experience.

Effective instructional models exist, such as high-quality feedback (Hattie \& Anderman, 2019), content-rich learning and engaging activities (Tankersley, 2005; Wexler, 2019b), and high-leverage practices (Linder \& Hayes, 2020). Evidence from the field, both anecdotally and from research, showed there was a business-as-usual approach. Schools reproduced what happened physically and recreated the practices online. Though Coker (2020b) suggested, along with others, to transform schools to include an "all hands on deck" approach, where staffing would be changed to put every staff member in the class and blur the lines of one teacher, one classroom, most all schools resisted reforming legacy models. The Spring of 2020 was reproduced in the Fall. Most online and remote classes continued age segregation led by one teacher. What teaching assistants, administrators, and support personnel did remain a mystery. Schools could become a "teachers without walls," where every staff member worked to increase engagement, interactivity, and high-class tutoring.

Many national organizations developed frameworks to restructure and improve education. Coker (2020a) found the theme which bound most frameworks together was the idea of a progressive curriculum (Figure 1). The calls to make the new curriculum happen meant new roles and competencies for teachers, different scheduling, and identifying vulnerabilities of students to remedy learning loss.

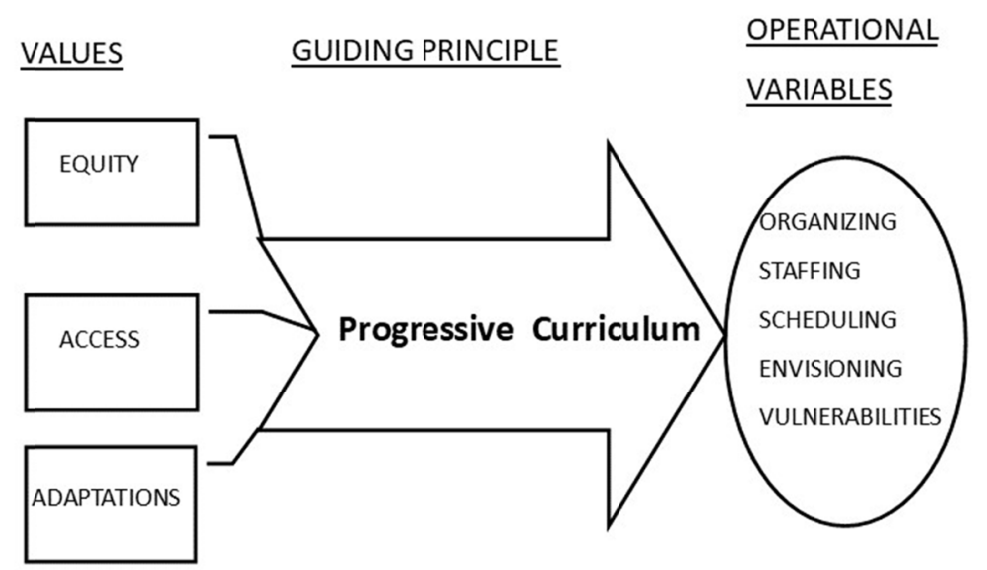

Figure 1. Curriculum framework to reopen schools

Note. Reprinted from "The Canary in the Mine: Remote Learning in the Time of COVID-19," by D. C. Coker (2020), Journal of Curriculum and Teaching, 9(3), 80. Reprinted with permission.

The revolution did not come. Education went on autopilot. Interviewing local and national policy makers revealed the vast majority of students did not work compared to pre-COVID-19. Many schools had $80 \%$ or more students doing little to no work, even if students were connected. Several states measured attendance for the day if there was 
any contact, from a text message to a login, making statistics unreliable. An example from Illinois demonstrated the new attendance expectations: "If the attendance method covers a week timespan (e.g., a weekly packet), then once the packet comes back completed the student should be marked present for each of the days the work packet was intended to cover" (Illinois State Board of Education, 2020, p. 1). There continued to be evidence worksheets given to students without Internet access were little more than busy work (Malkus \& Christensen, 2020). Another question remained: How did juvenile delinquents perform during the COVID-19 crisis?

Juvenile delinquents have, as a group, a long history of low academic achievement and an incongruent, poorly reflected appraisal (Blomberg \& Pesta, 2017; Walters, 2020). Much higher rates of mental illness compounded the problem of poor educational attainment (Lindberg et al., 2017). Once released, juvenile delinquents have behavioral problems in school and a much higher rate of dropping out of high school (Benner et al., 2016; Jaggers et al., 2016).

Juvenile detention centers, as presently managed, have few effective instructional practices and have shown little success in improving graduation rates (Benner et al., 2016; Eren \& Mocan, 2017; Hirsch et al., 2018). Interventions and practices often lacked fidelity and long-term success, and some researchers recommended juvenile detention centers should focus on individual factors (Gearhart \& Tucker, 2020; Pyle et al., 2020). The education of juvenile delinquents proved difficult before COVID-19, but there were no concerted programs to bridge the gap between the needs and demands of remote and online learning.

A search of EBSCO, ERIC, and Google Scholar did not find any research articles about juvenile delinquents and learning during COVID-19. The following review provided a first impression of juvenile delinquents and remote and online learning. A mixed methods research framework was used to close the gap in the literature.

\section{Mixed Methods}

A mixed methods approach is a research methodology which combines the best elements of the two traditional methods of research: qualitative and quantitative (Johnson et al., 2007). A convergent mixed methods typology was selected to describe the complexities of the involvement of stakeholders (Creswell \& Clark, 2017) while also showing the interaction with school during COVID-19. Qualitative methods were the primary method for research, with quantitative methods complementing broader social concerns (Leech \& Onwuegbuzie, 2009).

The study had three stages: a qualitative literature review of education policy concerning learning challenges during COVID-19, a grounded theory study about problems faced by teachers, and a case study of juvenile delinquents' schooling experiences during remote learning because of COVID-19. Mixed methods resulted in the disparate findings and inferences being combined in a meta-synthesis (Onwuegbuzie \& Johnson, 2006). All three parts were presented individually, and a discussion interweaved the disparate parts into a coherent whole. Recommendations for future research were then given.

\subsection{Qualitative Literature Review: Methods}

A qualitative literature review gives a representation of the problems between different literature sources and should provide a systematic analysis of the research and a gap (Onwuegbuzie et al., 2012). Creswell, echoing similar findings of other researchers, found four to five articles were sufficient to provide saturation for a qualitative literature review in a case study (Onwuegbuzie et al., 2016). The aim of the qualitative literature review was to answer the following question: What education policies were implemented to reopen schools to respond to learning challenges wrought by the transition from face-to-face learning to remote and online learning? Grounded theory using the constant comparison method was used to evaluate five articles about learning in the time of COVID, with care to ensure the original intent was not lost (Glaser, 1965; Rozas \& Klein, 2010). Following the recommendations of Saldaña (2015), there were three levels of coding: initial description, themes developed, and a theory. Coding, for grounded theory, started with in vivo and descriptive coding, with concomitant use of process, focused, and axial coding. Memoing and theming were used throughout the process to develop a substantive theme.

A search of articles about educational policies to restart school during COVID-19 was conducted. Search terms were COVID-19, corona/coronavirus, school, education/educational policy, learning, teaching, and academic achievement. ERIC, Google Scholar, and Microsoft Academic were searched. Articles which met the parameters about education policy concerning learning and teaching during the time of COVID-19 were included. The list was not intended to be exhaustive, but a search was conducted until enough articles were located to give a comprehensive view. As shown in Table 1, five articles were included. 
Table 1. Learning guidelines for COVID-19 in 2020

\begin{tabular}{|c|c|c|}
\hline Authors & Title & Type \\
\hline $\begin{array}{l}\text { Bacher-Hicks, A., Goodman, J., } \\
\text { \& Mulhern, C. }\end{array}$ & $\begin{array}{l}\text { Inequality in household adaptation to schooling shocks: } \\
\text { Covid-induced online learning engagement in real time } \\
\text { (No. w27555). National Bureau of Economic Research. }\end{array}$ & $\begin{array}{l}\text { Examined Google Trends for searching for } \\
\text { alternatives due to school closures due to } \\
\text { COVID-19 }\end{array}$ \\
\hline Borman, G. D. & $\begin{array}{l}\text { What can be done to address learning losses due to school } \\
\text { closures? Policy Analysis for California Education. }\end{array}$ & $\begin{array}{l}\text { Review of findings to combat the summer } \\
\text { and COVID-19 slide }\end{array}$ \\
\hline $\begin{array}{l}\text { Darling-Hammond, L., \& } \\
\text { Hyler, M. E. }\end{array}$ & $\begin{array}{l}\text { Preparing educators for the time of COVID... and beyond. } \\
\text { European Journal of Teacher Education. }\end{array}$ & $\begin{array}{l}\text { Recommendations to improve } \\
\text { social-emotional and academic outcomes }\end{array}$ \\
\hline $\begin{array}{l}\text { Dorn, E., Hancock, B., } \\
\text { Sarakatsannis, J., \& Viruleg, E. }\end{array}$ & $\begin{array}{l}\text { COVID-19 and student learning in the United States: The } \\
\text { hurt could last a lifetime. McKinsey \& Company }\end{array}$ & $\begin{array}{l}\text { Modeling different scenarios of returning to } \\
\text { school or remote/online learning and } \\
\text { outcomes for students }\end{array}$ \\
\hline Poletti, M. & $\begin{array}{l}\text { Hey teachers! Do not leave them kids alone! Envisioning } \\
\text { schools during and after the coronavirus (COVID-19) } \\
\text { pandemic. Trends in Neuroscience and Education. }\end{array}$ & $\begin{array}{l}\text { Policy review to develop interactivity and } \\
\text { engagement }\end{array}$ \\
\hline
\end{tabular}

All articles were read in the entirety first. Using Microsoft Excel, Microsoft Word, and Wordclouds.com, codes, memos, themes, and theories were developed. Legitimation established the trustworthiness and credibility of the qualitative literature review by confirming themes and theory matched the original intent of the authors (Onwuegbuzie et al., 2016). A comparison of previous research checked to see if other researchers found similar results.

\subsection{Qualitative Literature Review: Findings}

The quality of learning during COVID-19 was a major concern when schools transitioned from face to face (F2F) to online and remote learning. The constant comparison method was used to describe the results, distill main ideas and themes, and develop a substantive theory.

Three key themes emerged from the data: need for collaboration differently than present school organization, high expectations for all students, and personal, professional, and organizational accountability. All themes coalesced around the central idea of developing a community to support engagement, social connection, and a system of care.

A theory explained the response to academic achievement during the shift from face to face (F2F) to remote and online learning: Schools must replace the current mode of operation and dismantle the current power structure to develop a system which works to raise all students' level of achievement. The driver of the system would be a new community with staffing, scheduling, and the school day arranged in innovative ways. First, there is an explanation of the themes, and then a theory of how all themes can drive innovation was presented.

Collaboration conjures many meanings, depending on the person and organization. The central basis for collaboration was a rejection of the status quo from top to bottom. In-person and remote and online learning pose challenges and threats which need innovation and upheaval of the current system. For most schools, before COVID-19 hit, technology was on the fringe, with schools more traditional than modern. At the onset of COVID-19, "53\% of teachers reported" using technology as an add-on versus the primary tool.

A new model would mean schools would create a system of teachers to work together, using "the most expert teachers" to support others and the development of "flexible staffing models." Well-developed collaboration produces "higher job satisfaction, self-efficacy, and use of innovative practices." The new system of collaboration was needed more than ever, as COVID-19 increased the "wall of social isolation," with high-income parents trying to avoid the new normal by purchasing services. New functions and new connections must drive a system of collaboration; the unfortunate reality was before the pandemic, most teachers remained in one classroom, performing with little connection and teamwork.

High expectations have long been a mantra of school improvement initiatives, but COVID-19 exacerbated the disparate results for many groups. Online school produced greatly inferior results for most cohorts of students before the pandemic forced closure. The transition to remote and online learning must refocus the goal of teachers to assist all students to be successful through meaningful relationships, specific expectations, and an interactive and engaging environment. Many students were left behind, as a large percentage of students did not "receive any instruction" due to the pandemic.

Online and remote school must be more than new curricula, as students' "social and emotional experiences" and 
ability to apply "cognitive and metacognitive strategies focused on deeper learning" improve student outcomes. Parents of higher socioeconomic status increased searches for alternatives to traditional schools "twice as much," but students of lower socioeconomic status lacked the resources, so schools must "keep the most vulnerable students top of mind." Teachers cannot go it alone, so new expectations must be conveyed to parents and caregivers, as caregivers' efforts "to engage with their children" can improve academic outcomes. The translation of higher expectations to online and remote learning will require educators to "rethink not only spaces and times but also activities and curricula."

The final theme researchers presented was accountability, but accountability was different than traditional definitions. Instead of reliance, some would say overreliance, on test scores, the new system of collaboration and higher expectations "raised the bar for educators and educator preparation." Socioeconomic status (SES) should be a consideration, as students of lower SES were stuck in a new, questionable system with little hope of making gains even if in attendance. Students with "higher income, greater Internet access, and fewer rural schools" will probably have less learning loss than students who were "low-income, Black, and Hispanic." Evidence suggested accountability also will assist in improving collaboration and the adaptation of high expectations, as "millions of test scores" revealed calamitous learning loss, with even worse outcomes "for children with special needs." Darling-Hammond and Hyler (2020) called for rejecting "closing the achievement gap" in favor of improving the educational outcomes for all children.

A substantive theory connects the themes of collaboration, high expectations, and accountability: Schools needed a community of stakeholders which upsets the power structure and redefines staffing, scheduling, and the school day to reach the whole child. Past results found online and remote learning were "relatively less effective," and the forced decision of "continued remote learning" must give way to "upheaval." Breaking down barriers, which also existed in the execution of response to intervention (RtI), social-emotional learning (SEL), and special education, means creating a space where all stakeholders, from teachers to students to community members, develop and sustain rich, meaningful relationships predicated on the individual and academic achievement.

Legitimation means establishing credibility and trustworthiness that results match the findings of the original researchers (Onwuegbuzie et al., 2012). Glaser (1978) provided three means to check emergent theory was from findings and not researcher biases: fit and relevancy, workability, and modifiable. The findings were derived with thick descriptions and examination of themes with the original sources. Finally, the themes and theory provided a functional, viable direction for researchers and practitioners. The connection of the themes as support for the theory of development of community, as shown in Figure 2, gave a framework for the development of an effective remote and online learning system.

\begin{tabular}{|ll|ll|ll|}
\hline $\begin{array}{l}\text { Community } \\
\text { Engagement }\end{array}$ & \multicolumn{3}{l|}{ Cocial Connection } \\
\hline Collaboration & Busting Silos & High & Curriculum Map & Accountability & Teacher/Student \\
& Integration & Expectations & Feedback & & School \\
& Staffing & & Assessments & & District \\
\hline
\end{tabular}

Figure 2. A framework for effective online and remote learning

\subsection{Voices of Teachers}

What do teachers in the United States think and feel about the transition from F2F to online and remote learning? The voice of teachers described what and how practitioners felt about the transition to online and remote learning. Examining the experiences of teachers give insight into the connection between what experts recommended and what happened in practice.

Methods. Teachers' feelings about remote learning were examined from a blog where teachers described the experiences of shifting to online and remote learning as a result of COVID-19. Grounded theory is a method of constant comparison which develops a description of an event through the systematic analysis of coding, memoing, and theorizing to explain context, causes, and consequences (Glaser, 1978; Strauss \& Corbin, 1997). The penultimate goal of grounded theory is to fit a theory which emerges from the data and possesses utility with the events researched (Charmaz, 2006; Glaser, 1965; Saldaña, 2015).

Coding is a method to analyze the data by breaking the whole into smaller parts, but the analysis must remain faithful to the original intent of the participants of the study (Gibbs, 2018; Glaser \& Strauss, 1967). To develop an analysis and theory, three steps were used simultaneously, with in vivo, descriptive, and process coding to 
start, development of focused and axial coding, and ending with memoing, theming, and a narrative (Elliott, 2018; Saldaña, 2015). There was a goal of theoretical saturation, and the analysis was checked with the original data to ensure reliability and validity.

Sample. A sample of teachers' thoughts about online and remote learning was available on a blog from an article by Noonoo (2020). Convenience sampling was used, as the sample was easy to access and had similar characteristics (Etikan et al., 2016). The only demographic datum was the members of the sample self-represented they were all teachers on a website which everyone signed up to discuss concerns with online and remote learning.

Data Collection and Data Analysis. All records were publicly posted, with no names, locations, positions, or ages posted. To track each poster, each blog was copied into Microsoft Word and assigned a code (X1, X2, etc.). Microsoft Excel and Wordclouds.com were the programs used to develop codes, memos, and themes. Once theoretical and data saturation were reached, the analysis concluded. There were thirty postings analyzed. A journal was kept examining reflexivity to minimize bias and errors.

Results. The teachers, as a group, expressed three key ideas: survival, surrender, and despair. Teachers spoke most frequently in first person, and the most common problem was around survival: "I'm exhausted," "I can't keep up," and "I never get ahead." On and on, the teachers spoke about the inability to make it, so the teachers surrendered. X16 stated, "I hate that I don't care as much, but I'm relieved, too." Others agreed surrender was the best method. Teachers believed there was an inability to cope: "feeling like a failure with no way to fix or improve," and "I never get ahead." The foreboding appeared in most postings, with words of "unsupportive," "blaming," and feelings of "ineffectiveness."

Interpretation. While there was occasional hope ("familiar was mediocre at best" and "filled with a sense of hope"), the majority spoke of disillusionment which revolved around the deep-seated feeling of a loss of professionalism. When teachers lost the sense of professionalism, especially when feeling confident in the not-so-recent past, the disequilibrium resulted in the loss of personal power and agency. In a sense, the pandemic wrecked the definition of self and created a powerlessness exacerbated by fears of the unknown. A lack of linearity in understanding one's location and future movement created a paralysis as disorientation set in.

Two root causes underpinned the disillusionment and loss of sense of professionalism. First, teachers overtly stated they neither understood technology nor had effective methods to build meaningful, sustained virtual classrooms. The conclusion could be teachers could not effectively and efficiently use technology before the pandemic, despite widespread adoption of technology. Secondly, teachers had an inability to cope to with the paradigm shift. Unlike F2F in a school building, teachers no longer were afforded the chance to lean on colleagues or meet with administrators. Isolated and alone, teachers had to deal with problems without the traditional support network.

Teachers no longer had a balance on the life-work continuum. Not surprisingly, many teachers recognized the need to do more than simply send everyone home and recreate F2F virtually (X19: "it is unfair" and X17: "I'm upset we spent a summer reimagining ... yet we continue to do the opposite"). Educators felt the new medium and context wrecked relationships, competence, and ultimately learning. Resiliency was tested beyond anything most teachers had faced before, as many felt no way out. The lack of agency created a disengagement, as teachers needed to eke out an existence which did not include the central goal of schools: learning.

Validity and Reliability. Establishing trustworthiness and credibility relies on using multiple sources of data to confirm themes and conclusions (Flick, 2018). First, an examination of the continuing blog at a later time revealed similar feelings of lack of professionalism and agency as well as producing no new themes. Secondly, other researchers found similar results of despair, survival, and surrender (Haverback, 2020; MacIntyre et al., 2020). Thirdly, anecdotal data from interviewing other teachers from districts across the nation revealed similar concerns and issues.

There was credibility, as the results were drawn from the data and had a consistency throughout (Charmaz, 2006; Patton, 1999). Alexander (2020) stated qualitative research infuses the researcher's beliefs and values into the findings. Still, using thick descriptions and checking reflexivity, the findings had a dependability with the voices of teachers and appeared transferable to many, even possibly most teachers.

\subsection{Case Study of Juvenile Delinquents and Distance Learning}

An instrumental case study approach was chosen because the study of juvenile delinquents during the COVID-19 pandemic was complex, needed multiple data sources and methods to analyze, and the results could be used to improve services (Fossey \& Crow, 2011; Phondej et al., 2011). Yin (2018) stated a case study 
explains the how and what, defines units of analysis, and offers propositions to hypothesize what was observed. Compared to other methods, a case study is an applied research problem which proposes a solution and a theoretical angle (Hancock \& Algozzine, 2017). All names and personal identifying information were redacted to protect anonymity and maintain confidentiality. The research questions, sample, data collection, and data analysis describe the systematic method to investigate the problem.

How were juvenile delinquents faring during the pandemic, and what policies recommendations can improve the situation? The word faring offered the proposition juvenile delinquents were found to be poor readers, showed little engagement before the crisis, and suffered from mental and emotional problems which would complicate a transition to distance education. Since juvenile delinquents, as a group, struggled with the rules and norms of traditional school, there was the hypothesis the new school modality would not be successful with juvenile delinquents unless drastic changes were implemented. The case study examined units of analysis by the student level (the juvenile delinquent), the facility level, and compared attendance to the broader geographical area. Data collection focused on demographic data, assessments of juvenile delinquents, archival review of school records, brief interviews, and examination of local school districts' attendance and enrollment patterns. An archival review of records was conducted.

The sample was bifurcated by a baseline sample from Fall 2019 (for students enrolled September 1 to October 31, pre-pandemic; $N=23$ ) and a COVID sample from Fall 2020 (selected from September 1 to October 31 during the pandemic; $N=28$ ). The setting was from a small, Midwestern juvenile detention center in the United States which served a mostly rural area in a short-term capacity (most students detained $<30$ days). All juveniles had been charged with a delinquency and been ordered detained until trial. Three teachers per day were present, with students on a block schedule. Electives and interventions also included use of laptops. Students were mostly male in both samples (baseline $=100 \%$, COVID $=93 \%$ ). A breakdown of demographics showed the group differences in Table 2, with the conclusion the groups were very similar in age, grade, and other factors relating to background except in special education.

Table 2. Demographic data

\begin{tabular}{lll}
\hline Measure & Baseline & COVID \\
\hline Age & $M=15.48 ; S D=1.47 ;$ Range $=12-17$ & $M=15.64 ; S D=1.10 ;$ Range $=13-17$ \\
Gender & Males $=100 \%(N=21) ;$ & Males $=93 \%(N=26) ;$ \\
& Females $=0 \%(N=0)$ & Females $=7 \%(N=2)$ \\
Race & Black $=48 \%(N=10)$ & Black $=46 \%(N=13)$ \\
& White $=57 \%(N=12)$ & White $=54 \%(N=15)$ \\
& Hispanic $=5 \%(N=1)$ & Hispanic $=0 \%(N=0)$ \\
Grade Level & $M=9.83 ; S D=1.11 ;$ Range $=8-13$ & $M=10.04 ; S D=1.47 ;$ Range $=7-13$ \\
Special Education & $19 \%(N=4)$ Special Education & $32 \%(N=9)$ Special Education \\
& $29 \%(N=6)$ Unknown Special Education ${ }^{\mathrm{a}}$ & $29 \%(N=8)$ Unknown Special Education ${ }^{\mathrm{a}}$ \\
\hline
\end{tabular}

Note. Baseline $N=23$; COVID $N=28$; a. Unknown $=$ Never received records.

All students at the juvenile detention center were enrolled in a school which operated on an A/B block schedule, with all four core subjects (two subjects per day) and daily physical education. Students who entered the juvenile detention center completed a comprehensive evaluation, where all students took assessments to determine a functional placement. For reading and mathematics, students completed the Test of Adult Basic Education (TABE), Basic Achievement Skills Inventory-Short (BASI-S), and the Test of Silent Contextual Reading Fluency-2 (TOSCRF-2). Students also completed a qualitative measure comprised of 25 questions covering the following mathematical skills: addition, subtraction, multiplication, division, decimals, fractions, and pre-Algebra. The unstandardized test was called the Basic Math Achievement (BMA). Concerning social and emotional conditions, students completed the following questionnaires: State Self-esteem Scale (SSES), Grit-Short, Marsh's Math Academic Self-concept (ASC), Marsh's Language Arts Academic Self-concept (ASC), and the Strengths and Difficulties Questionnaire (SDQ). Besides the BMA, all tests had adequate validity and reliability (Broxterman et al., 2017; Duckworth \& Quinn, 2009; Dumont et al., 2013; Goodman, 1997; Heatherton \& Polivy, 1991; Marsh, 1990; Robins et al., 2001).

Statistical tests to compare differences in academic, social, and emotional assessments for the baseline and comparison groups were conducted using Jeffrey's Amazing Statistics Program (JASP Team, 2020). JASP (Version 0.14) [Computer software]). Welch's t-test was chosen, but if there were problems with either normality and, or homogeneity of variance, the Mann-Whitney U test was performed. As shown in Table 3, the baseline and 
COVID groups were similar on all instruments. While the results of the SDQ were not significant, practical differences were significant. The SDQ measures students in three categories: normal, borderline, and abnormal. For the baseline group, three students were borderline (14\%) and four were abnormal (19\%). In the COVID group, four students were borderline (15\%) and 12 were abnormal (46\%). The discrepancy might be explained by special education status, as special education students, students with 504 plans, and students unknown if special education were greater in the COVID group than the baseline group. Still, the abnormally high number of special education students might be indicative of students with disabilities having a higher rate of delinquency in the interim, as the small sample can fluctuate widely month to month.

Table 3. Student assessments by COVID group and baseline group

\begin{tabular}{|c|c|c|c|}
\hline Measure & COVID $N, M, \& S D$ & Baseline $N, M, \& S D$ & Statistic, $\alpha$ level, $\& \mathrm{df}$ \\
\hline \multirow[t]{3}{*}{ TABE Reading GE } & $N=21$ & $N=26$ & $t=-0.600^{\mathrm{a}}$ \\
\hline & $M=5.643$ & $M=6.181$ & $p=.553$ \\
\hline & $S D=2.671$ & $S D=3.474$ & $d f=44.913$ \\
\hline \multirow[t]{3}{*}{ TABE Math GE } & $N=21$ & $N=26$ & $t=-0.732^{\mathrm{a}}$ \\
\hline & $M=5.848$ & $M=6.515$ & $p=.469$ \\
\hline & $S D=3.428$ & $S D=2.662$ & $d f=37.172$ \\
\hline \multirow[t]{3}{*}{ BMA } & $N=21$ & $N=26$ & $t=0.384^{\mathrm{a}}$ \\
\hline & $M=51.143$ & $M=48.492$ & $p=.703$ \\
\hline & $S D=22.121$ & $S D=21.266$ & $d f=42.194$ \\
\hline \multirow[t]{3}{*}{ TOSCRF-2 Index Score } & $N=19$ & $N=23$ & $W=189.000^{\mathrm{b}}$ \\
\hline & $M=85.526$ & $M=86.435$ & $p=.463$ \\
\hline & $S D=10.992$ & $S D=10.121$ & \\
\hline \multirow[t]{3}{*}{ SDQ } & $N=21$ & $N=26$ & $W=193.500^{\mathrm{b}}$ \\
\hline & $M=13.174$ & $M=16.623$ & $p=.090$ \\
\hline & $S D=4.584$ & $S D=6.782$ & \\
\hline \multirow[t]{3}{*}{ SSES } & $N=20$ & $N=26$ & $t=1.036^{\mathrm{a}}$ \\
\hline & $M=72.500$ & $M=68.500$ & $p=.306$ \\
\hline & $S D=12.589$ & $S D=13.486$ & $d f=42.299$ \\
\hline \multirow[t]{3}{*}{ Grit-Short } & $N=17$ & $N=22$ & $t=-0.006^{\mathrm{a}}$ \\
\hline & $M=3.239$ & $M=3.240$ & $p=.995$ \\
\hline & $S D=0.613$ & $S D=0.653$ & $d f=35.536$ \\
\hline \multirow[t]{3}{*}{ LA ASC } & $N=17$ & $N=22$ & $t=1.181^{\mathrm{a}}$ \\
\hline & $M=15.882$ & $M=13.591$ & $p=.246$ \\
\hline & $S D=5.915$ & $S D=6.131$ & $d f=35.141$ \\
\hline \multirow[t]{3}{*}{ Math ASC } & $N=17$ & $N=22$ & $t=-0.444^{\mathrm{a}}$ \\
\hline & $M=14.412$ & $M=14.955$ & $p=.660$ \\
\hline & $S D=3.374$ & $S D=4.259$ & $d f=36.693$ \\
\hline
\end{tabular}

Note. $p=.05$ two tailed. TABE $=$ Test of Adult Basic Education. GE $=$ Grade Equivalency. BMA $=$ Basic Math Assessment. TOSCRF-2 $=$ Test of Silent Contextual Reading Fluency-2. SDQ $=$ Strengths and Difficulties Questionnaire. SSES $=$ State Self-esteem Scale. LA ASC $=$ Language Arts. ASC $=$ Academic Self-concept.

a. Welch's t-test

b. Mann-Whitney U test

The two groups differed significantly by school enrollment, both practically and statistically, as measured by Fisher's exact test (two-tailed, $p=.0019$ ). The baseline group, for Fall 2019, had the following breakdown of students by enrollment type: 8 drop out (35\%), 13 regular school (57\%), and 2 alternative education (7\%). For the COVID group during Fall 2020, the results were markedly dissimilar: 13 did not attend (46\%), 3 online regular school (11\%), and 6 alternative school (21\%). The drop in F2F attendance at traditional schools plummeted to zero, with few students choosing to partake in online public schools. The $32 \%$ overall attendance by the COVID group versus the $64 \%$ attendance by the baseline group did not compare to local attendance patterns, where enrollment for the county dropped by $8.9 \%$ (Regional Office of Education \#54, 2020).

A further component added to the shift in education. Of the three students, there were very dissimilar outcomes from a year ago pre-pandemic. There was a middle school student, a freshman, and a senior. The middle school student was failing all classes, with grades ranging from $25-37 \%$. What was the high point of his online day? When a teacher in a specialist class, Gateway to Technology, let the students mingle for five minutes before class began. On a scale of $1-10$, with 10 being the best, he rated school a 5. Similarly, the freshman student was failing 
all courses and rated school a 3. The third high school student attended another local high school, and he was passing five out of six classes, mostly with A's and B's. His official attendance record stated he attended 18 out of 36 days, or $50 \%$ of the time. He rated school a 5 . Attendance could mean simply responding to a text message, so the expectations moved from five to seven hours of attendance per day to sending out a one-word text.

A brief interview added to the nature of online school. All students stated the majority of instruction was asynchronous. Even synchronous did not mean what it should, as students stated most teachers spoke for 10-15 minutes and then left. One student stated he was "happy to return" to the juvenile detention center, as it "was impossible" to learn math on the outside. The middle school student offered an analysis incongruous with school records. He stated he attended regularly and was passing all his classes, though the opposite was true. He was similar to most students at his school, where students did appear online for some synchronous sessions, but the assignments were rarely completed individually. The senior was an outlier: He was an above-average student, and he had parental support and an upper-class background, unlike all the other students in the baseline and comparative sample. He pointed out the ease of copying and pasting into Google to facilitate completion of assignments.

Students, when given the chance to work independently, chose to complete little schoolwork. There seemed to be several reasons for this result. First, most students attended school without demonstrating learning. The TOSCRF-2 scores revealed the COVID group had $65 \%$ of students at or below the 25 th percentile, with only eight students in the average range. Reading ability was a barrier, with most students showing little improvement after elementary school. Secondly, all students had disruptive and defiant behavior, unless the students had major attendance issues. Being disruptive and preventing others from learning were the norms. Lastly, there was a disassociation of effort and achievement prior to the pandemic. Probably due in part to No Child Left Behind, schools responded to measuring high school graduation rates as a metric to judge schools as adequate by promoting students regardless of effort or achievement. There were many records of students missing greater than 75 to $87 \%$ of the time and still passing most, if not all classes (some specific examples included missing 104/119 days and passing three classes; another student attended 35 days in middle school and was expelled, but his grades were still sufficient for him to be promoted under the school's standards). Receiving even more than 100 office referrals did not prevent many students from being promoted, as the students continued multiple times per day to disrupt learning and the feelings of safety of fellow students.

Before the pandemic, little learning, a do-what-you-want attitude, and show-up-as-you-please attendance led to the credential of promotion and, or graduation. The difference in online learning, for many students, seemed to be a lack of any discernible interest in logging in, watching a lesson, and completing work. Since doing the opposite of most requirements led to passing classes in traditional F2F school, there was the problem many students might believe they would still pass. Many students were doing comparable work. As one recent high school graduate at the detention center stated, he could not believe he passed at his old alternative school. A theme tied all the actions together: Move the students on no matter what. No one wanted them and retention did not work, so let every student suffer the disruptive behavior while also passing even when one did not work, and promotion kicked the can down the road.

\subsection{Limitations}

Triangulation checks for reliability and confirmability by considering results against theory, methodologies, researchers, and data analysis techniques (Flick, 2018; Thurmond, 2001). First, many other disparate researchers found similar results. Secondly, the mixed methods approach brought three different methodologies together. If others were to conduct the research on the juvenile delinquents and the teachers, the results could be confirmed with little variability.

Transferability of the teacher sample might be limited by the overwhelming number of negative responses; possibly the positive, optimistic teachers did not respond. Concerning the juvenile delinquents, one sample from a mostly suburban and rural area was used, so care must be exercised that juvenile delinquents in a larger metropolitan area might be different. Still, the sample was similar to the population of juvenile delinquents. As recommended by Decrop (1999), there was a search for divergence of the data, and little was found. By offering thick descriptions, checking results for fit with the original data, and practicing reflexivity by journaling, biases and errors were kept to a minimum.

\section{Discussion}

Three levels of research examined the nature of schooling for juvenile delinquents, with broader implications for all schools in a remote and online environment. There was a gap in the literature, as no articles or studies were identified which described the experiences of juvenile delinquents during COVID-19. Online and remote 
learning as a means of instruction suffered from little evidence of effective, research-based practices (Linder \& Hayes, 2020), with most students preferring F2F over online and blended learning (Alvarado-Alcantar et al., 2018; Mills et al., 2018). The discussion is broken down into two components: A description of the interweaving of the findings and a policy proposal to improve services for juvenile delinquents and all students.

Researchers called for the development of a sense of community online, with collaboration, high expectations, and accountability. Other researchers issued similar calls for envisioning a new system around staffing, organization, and scheduling, as reviewed in Coker (2020a). The disparity between researchers' utopian dreams and the practices of lived experiences of teachers and juvenile delinquents was daunting and painted a picture of bewilderment, lack of connectivity, and lack of a sense of accomplishment. There was a cascade of failure, with the idea of community becoming a dystopian nightmare where teachers neither possessed the skills nor the competence to translate past practices into a successful virtual environment. For juvenile delinquents, school failed to meet their needs before, and instead of attending F2F and wrecking the experience of other students, delinquents saw little point in the purpose of school-learning. Still, the result meant most juvenile delinquents had zero chance of improving academic skills within a school setting, which existed for many students in public school as well (Clancy \& Sentance, 2020).

Juvenile delinquents were on the margins before COVID-19, not settling into traditional roles of students and being dispossessed after incarceration (Kubek et al., 2020). Social and emotional problems defined juvenile delinquents, with many attending schools as disruptors and for socialization over academics. Well-meaning laws, such as No Child Left Behind, initiatives to reduce school exclusionary polices (Curran \& Finch, 2020), and lack of grade-level retention (Jacob \& Lefgren, 2004) resulted in a situation where effort, achievement, and attendance were often not required for promotion. Many students, including juvenile delinquents, did not find schools safe, welcoming places before the pandemic (Berkowitz et al., 2017; Shukla et al., 2016).

The three levels of analysis revealed experts suggested community development as a means to improve online and remote learning, but most teachers had no concrete way to translate the abstract into reality. The absence of communal support and the chance to reappraise and reframe the situation meant teachers lacked a meaningful network to cope with persistent failure (Flook et al., 2013; Lyons et al., 1998; McRae et al., 2012). Further compounding the problem was juvenile delinquents lacked the requisite will or skill to be successful. Sadly, for many students and especially juvenile delinquents, school learning might not be much different whether one attended or not. The paradox was not lost, as students not on the extremes were also suffering from a teaching modality which was mostly teacher led and utilized the equivalent of high-tech worksheets.

To improve school for teachers and students, the community must adopt a theory of humanistic schooling by becoming a community of learners, with four dimensions: physical health, academics, social, and the personal. As shown in Figure 3, a transformation will be needed to completely change present practices. A brief, fictional example of the current situation describes the dilemma. Schools moved to a dystopia like out of the sci-fi movie Terminator. Imagine walking into a classroom and the students sit the entire period, watching the teacher. After the teacher finished instruction, the students started a worksheet with a zero possibility of interaction and connection with another living soul. No hands go up. Feedback will be another day. At the end of class, each student was escorted out one by one, often being rolled out in a chair to the next class without seeing any other students or staff members. No one knows anyone. Like in Ralph Ellison's Invisible Man, students existed but were not seen, and unlike the Terminator franchise, no one will be back.

Toward a Theory of a Humanistic Schooling Experience

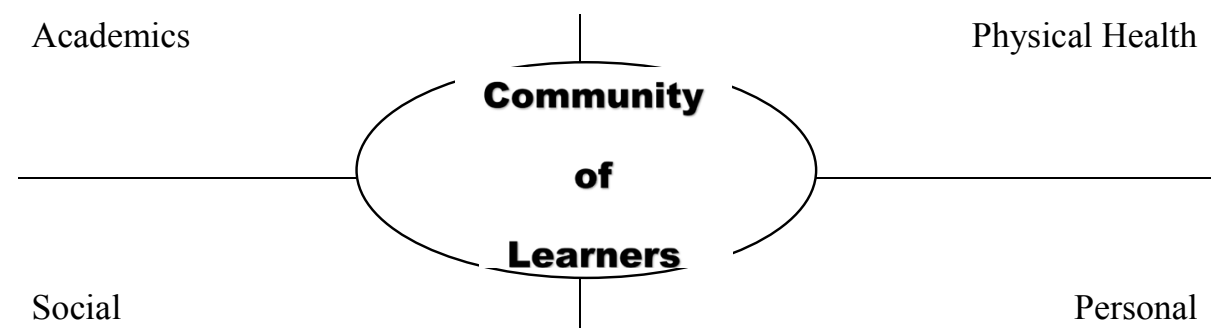

Figure 3. The framework for a theory of humanistic schooling 
There were calls for improvement, but a major hurdle hindered the development of humanistic schooling and the resultant community of learners: Few knew what a good lesson plan looked like online, and even if a teacher did, most lacked the technological competence. Schools have a guide, though, as research suggested many factors, such as classroom management, supportive climate, cognitive activation, responsiveness, and caring teachers create effective classrooms (Brophy, 1986; Murphy et al., 2004; Praetorius et al., 2018; Robinson \& Lewis, 2017). Within many schools, professional learning communities existed which did not produce meaningful collaboration. Current practices make little sense for every classroom in the nation to each develop a model which was not theory based, evidence driven, and lacked basic collaborative planning.

Beyond academics, three components, with few researchers connecting all three to the main goal of learning and teaching, were missing: physical health, social, and the personal. All four components, academic, physical health, social, and the personal, collectively make up the schooling experience. Asking students to sit all day and listen to a teacher violated every professional norm developed extensively over the past 50 years. There was emerging evidence during COVID-19 the shift to online and remote school resulted in a lack of physical activity and isolation, leading to a sedentary lifestyle and a deterioration of mental health, with an increase in depression and anxiety (Carter et al., 2020; Golberstein et al., 2020; Kang et al., 2020; Loades et al., 2020; Rundle et al., 2020). While other researchers recommended best learning practices (e.g., Fisher et al., 2020), schooling was largely missing in the legacy models. The physical health component requires exercise and movement; social means students bust out of isolation; the personal results in students knowing and feeling valued from others, but especially from a caring, concerned adult.

Schools can transform the model of sit, listen, and work independently by developing three aspects. First, schools need to be truly collaborative. Instead of each teacher in a building developing a lesson, a group-local, state, and nationally - can develop, disseminate, and track exemplars. Secondly, any new modalities must be a "grab and go activity," where teachers can quickly and with little effort implement the new structure. Thirdly, what teachers were doing must look and feel vastly different from anything attempted before. That is, teachers must reject the current structure in its entirety and refashion it.

A humanistic schooling theory of a community of learners must center on a visionary structure which retools the roles, contexts, and connections of transactional power. Students and staff members must speak before, during, and after class for the majority of the time, possibly through avatars and virtual reality elements. A curriculum which incorporates direct instruction with problem-based and passion-based learning, replete with virtual lunchrooms and passing periods, could bridge the divide between teacher-dominated time and students' social and personal needs. The physical must be incorporated, as students and teachers should not sit all day. Some suggestions include the following to integrate the physical world to the virtual world: physically completing assignments and projects and sending in pictures and videos, calisthenics during class, virtual extracurriculars with physical requirements, planned movements, and frequent breaks calling for a disconnect from technology. Students could also act out answers and carry out demonstrations.

Distance education, especially for students less prepared, has a poor track records compared to traditional school (Garcia \& Weiss, 2020). Yet, place a student in front of a video game or hand a student a cellphone, and students will be online all hours of the day. The students were still sitting, but the engagement and interactivity were astounding compared to sitting, listening to a teacher, and completing an online worksheet by oneself. Back in the 1990s, when students were taught to design websites, there was an adage: Do what the best, like Amazon, did. Online education has an exemplary model of interactivity, and there could be dimensions incorporated into the public schools to make the curriculum interactive, engaging, and relevant.

Guskey and Passaro (1994) found successful educational communities had a locus of control guided by the participants; in practice, the results would be classrooms could continue to have substantial variation, such as a $1^{\text {st }}$ grade classroom would carry out practices much differently than 10th grade. To develop dimensions of effective online instruction transformed into schooling, several mechanisms could guide practitioners and researchers. First, ratings and scales could evaluate the new classroom normal. A community of learners around academics, social, physical, and the personal could focus on the following dimensions on a 1-10 scale: engagement, personal expression, interactivity, social, physical health, knowing one adult well, assignment completion, academic rigor and relevance, and hybridization. These recommendations are a starting point, but all instruction must have an element of personalization, offer timely feedback, remediation, and demonstration of mastery. Hybridization would mean disconnecting with technology, which might include reading books, writing papers, and constructing projects and presentations.

The new model must coalesce around learning. Though the scale has not been tested, there have been informal 
comparisons of the four dimensions to many classrooms around the nation, and the current results were not promising. Teachers were not producing comparable learning to in-person learning, making the sustainability of the traditional school day questionable both before and during the pandemic. Instead of continuing the compartmentalization of discrete subjects, especially art, music, and other electives, an interdisciplinary approach could improve learning, engagement, and the fun factor. The current schema of each teacher an island, each student a passive vessel, must give way to all staff members having a direct impact on instruction.

The theory of humanistic schooling of a community of learners is well supported by research and past practices, and yet the aims which were a major focus before COVID-19 had little support in online and remote education. First, educating the whole child and building the capacity for social and emotional learning have been major initiatives to improve relationships and connectivity of students to school (Collie et al., 2012; Panayiotou et al., 2019). Physical health was also predictive of school success (Silva et al., 2019), and adverse childhood experiences have a well-established connection with school problems (Robles et al., 2019). A humanistic schooling paradigm shifts present conditions which were much more like college, where students work independently, sit for lectures, and are self-motivated, to a much more fluid, dynamic environment.

Were students learning less during remote and online learning? The unfortunate reality was for juvenile delinquents, and one suspects many other students, the answer might be a resounding no. Innovation will require rejecting the present models and assumptions for classrooms which recreate a schooling experience. Thinking YouTube and video games, instruction must move beyond a learning management system which, as one colleague put it, produced "death by online forms." A temporal and spatial reformatting must take place for the mental, physical, and social health of teachers and students. Alvy (2017) warned of fads and quick fixes. Yet, the recommendations are the opposite of fads: engagement, interactivity, care, social, physical, and academic rigor.

\section{Conclusions}

Estimates indicated possibly three million students in the United States went missing from enrollment once COVID-19 hit (Korman et al., 2020), with students from a low socioeconomic status possibly the hardest hit (Chetty et al., 2020). Students reentering school will probably be further behind and have greater variation in academic skills (Kuhfeld et al., 2020). Nowhere in the debate have juvenile delinquents' education on post-release been mentioned, and preliminary results suggested juveniles involved in the criminal justice system might be marginalized and invisible.

Teachers were in a crisis, with the burden of trying to learn new technology and modes of operating, and the results hurt equity initiatives and attendance (Carver, 2020; Kaden, 2020). Schooling, as presented as a policy recommendation to inculcate a community of learners, recognizes the problems pointed out by Vegas and Winthrop (2020), who stated educators and interactions should be the drivers of successful distant learning, not technology or gadgets. The schema of one teacher, one classroom, nevertheless persists and continues to marginalize and harm students by failing to build the capacity and agency of meaningful social and personal connections, with poor physical health a looming challenge. In the entire debate, learning as a policy must become an end goal which moves beyond lessons and curricula to center on the full range of the schooling experience which nurtures the whole child.

\section{References}

Alexander, P. A. (2020). Methodological guidance paper: The art and science of quality systematic reviews. Review of Educational Research, 90(1), 6-23. https://doi.org/ 10.3102/0034654319854352

Alvarado-Alcantar, R., Keeley, R., \& Sherrow, B. (2018). Accessibility and usability of preferences in blended learning for students with and without disabilities in high school. Journal of Online Learning Research, 4(2), 173-198. Association for the Advancement of Computing in Education (AACE). Retrieved from https://www.learntechlib.org/primary/p/181294/

Alvy, H. (2017). Fighting for change in your school: How to avoid fads and focus on substance. ASCD.

Bacher-Hicks, A., Goodman, J., \& Mulhern, C. (2020). Inequality in household adaptation to schooling shocks: COVID-induced online learning engagement in real time (No. w27555). National Bureau of Economic Research. https://doi.org/10.3386/w27555

Benner, G. J., Zeng, S., Armstrong, A. L., Anderson, C., Carpenter, E., University of Washington-Tacoma, \& United States of America. (2016). Strengthening education in short-term juvenile detention centers: Final technical report. Center for Strong Schools, University of Washington, Tacoma. Retrieved from https://www.ncjrs.gov/ 
Berkowitz, R., Moore, H., Astor, R. A., \& Benbenishty, R. (2017). A research synthesis of the associations between socioeconomic background, inequality, school climate, and academic achievement. Review of Educational Research, 87(2), 425-469. https://doi.org/10.3102/0034654316669821

Bettinger, E., \& Loeb, S. (2017). Promises and pitfalls of online education. Evidence Speaks Reports, 2(15), 1-4. https://doi.org/10.1016/j.econedurev.2017.03.006

Blomberg, T. G., \& Pesta, G. B. (2017). Education and delinquency. The Encyclopedia of Juvenile Delinquency and Justice, 1-5. Wiley. https://doi.org/10.1002/9781118524275.ejdj0044

Borman, G. D. (2020). What can be done to address learning losses due to school closures? Policy Analysis for California Education. Retrieved from https://edpolicyinca.org/publications/what-can-be-done-address-learning-losses-due-school-closures

Brenan, M. (2020, March 31). 42\% of parents worry COVID-19 will affect child's education. Gallup. Retrieved from https://news.gallup.com/poll/305819/parents-worry-covid-affect-child-education.aspx

Brophy, J. (1986). Teacher influences on student achievement. American Psychologist, 41(10), 1069. https://doi.org/10.1037/0003-066X.41.10.1069

Broxterman, K., Mok, D. S., \& Beukema, A. (2017). Basic Achievement Skills Inventory. In B. Caplan, J. Deluca \& J. S. Kreutzer (Eds.), Encyclopedia of clinical neuropsychology (pp. 1-3). https://doi.org/10.1007/978-3-319-56782-2_1440-2

Byun, J., \& Joung, E. (2018). Digital game - based learning for K-12 mathematics education: A meta - analysis. School Science and Mathematics, 118(3-4), 113-126. https://doi.org/10.1111/ssm.12271

Carter, S. J., Baranauskas, M. N., \& Fly, A. D. (2020). Considerations for obesity, vitamin D, and physical activity amid the COVID - 19 pandemic. Obesity, 28(7), 1176-1177. https://doi.org/10.1002/oby.22838

Carver, L. B. (2020). Supporting learners in a time of crisis. Advances in Social Sciences Research Journal, 7(4), 129-136. https://doi.org/10.14738/assrj.74.8109

Charmaz, K. (2006). Constructing grounded theory: A practical guide through qualitative analysis. Sage.

Chetty, R., Friedman, J. N., Hendren, N., \& Stepner, M. (2020). Real-time economics: A new platform to track the impacts of COVID-19 on people, businesses, and communities using private sector data. NBER Working Paper 27431. Retrieved from https://www.nber.org/

Clancy, D. S., \& Sentance, M. (2020). Keeping students academically engaged during the coronavirus crisis (part one. Policy brief). Pioneer Institute for Public Policy Research. Retrieved from http://www.pioneerinstitute.org

Coker, D. C. (2020a). The canary in the mine: Remote learning in the time of COVID-19. Journal of Curriculum and Teaching, 9(3), 76-87. https://doi.org/10.5430/jct.v9n3p76

Coker, D. C. (2020b). Revolution in remote learning: A plan for radical improvement. In EdMedia + Innovate Learning (pp. 329-343). Association for the Advancement of Computing in Education (AACE).

Collie, R. J., Shapka, J. D., \& Perry, N. E. (2012). School climate and social-emotional learning: Predicting teacher stress, job satisfaction, and teaching efficacy. Journal of Educational Psychology, 104(4), 1189-1204. https://doi.org/10.1037/a0029356

Creswell, J. W., \& Clark, V. L. P. (2017). Designing and conducting mixed methods research. Sage Publications.

Cuban, L., \& Jandrić, P. (2015). The dubious promise of educational technologies: Historical patterns and future challenges. E-Learning and Digital Media, 12(3-4), 425-439. https://doi.org/10.1177/2042753015579978

Curran, F. C., \& Finch, M. A. (2020). Reforming school discipline: Responses by school district leadership to revised state guidelines for student codes of conduct. Educational Administration Quarterly, 54(2), 275-302. https://doi.org/10.1177\%2F0013161X20925893

Darling-Hammond, L., \& Hyler, M. E. (2020). Preparing educators for the time of COVID... and beyond. European Journal of Teacher Education, 1-9. https://doi.org/10.1080/02619768.2020.1816961

Decrop, A. (1999). Triangulation in qualitative tourism research. Tourism Management, 20(1), 157-161. https://doi.org/10.1016/S0261-5177(98)00102-2

Dorn, E., Hancock, B., Sarakatsannis, J., \& Viruleg, E. (2020). COVID-19 and student learning in the United States: The hurt could last a lifetime. McKinsey \& Company, 3. Retrieved from 
https://www.childrensinstitute.net/

Duckworth, A. L., \& Quinn, P. D. (2009). Development and validation of the Short Grit Scale (Grit-S). Journal of Personality Assessment, 91, 166-174. https://doi.org/10.1080/00223890802634290

Dumont, R., Willis, J. O., Veizel, K., \& Zibulsky, J. (2013). Test of Silent Contextual Reading Fluency (TOSCRF). In C. R. Reynolds, K. J. Vannest \& E. Fletcher-Jonzen (Eds.), Encyclopedia of special education: A reference for the education of children, adolescents, and adults with disabilities and other exceptional individuals. https://doi.org/10.1002/9781118660584.ese2375

Elliott, V. (2018). Thinking about the coding process in qualitative data analysis. The Qualitative Report, 23(11), 2850-2861. Retrieved from https://nsuworks.nova.edu/tqr/

Eren, O., \& Mocan, N. (2017). Juvenile punishment, high school graduation and adult crime: Evidence from idiosyncratic judge harshness. Review of Economics and Statistics, 1-46. https://doi.org/10.1162/rest_a_00872

Etikan, I., Musa, S. A., \& Alkassim, R. S. (2016). Comparison of convenience sampling and purposive sampling. American Journal of Theoretical and Applied Statistics, 5(1), 1-4. https://doi.org/10.11648/j.ajtas.20160501.11

Fisher, D., Frey, N., \& Hattie, J. (2020). The distance learning playbook, grades K-12: Teaching for engagement and impact in any setting. Corwin Press.

Flick, U. (2018). Designing qualitative research. Sage.

Flook, L., Goldberg, S. B., Pinger, L., Bonus, K., \& Davidson, R. J. (2013). Mindfulness for teachers: A pilot study to assess effects on stress, burnout, and teaching efficacy. Mind, Brain, and Education, 7(3), 182-195. https://doi.org/10.1111/mbe.12026

Fossey, R., \& Crow, G. M. (2011). The elements of a good case. Journal of Cases in Educational Leadership, 14(3), 4-10. https://doi.org/10.1177\%2F1555458911426467

Fullan, M. (2013). Commentary: The new pedagogy: Students and teachers as learning partners. Learning Landscapes, 6(2), 23-29. https://doi.org/10.36510/learnland.v6i2.601

Garcia, E., \& Weiss, E. (2020). COVID-19 and student performance, equity, and U.S. education policy. Economic Policy Institute. Retrieved from https://www.epi.org/

García, M. T., \& Butrymowicz, S. (2020). Online programs used for coronavirus-era school promise results. The claims are misleading. USA Today. Retrieved from https://www.usatoday.com/

Gearhart, M. C., \& Tucker, R. (2020). Criminogenic risk, criminogenic need, collective efficacy, and juvenile delinquency. Criminal Justice and Behavior, 47(9), 1116-1135. https://doi.org/10.1177\%2F0093854820928568

Gibbs, G. R. (2018). Analyzing qualitative data (Vol. 6). Sage.

Glaser, B. G. (1965). The constant comparative method of qualitative analysis. Social Problems, 12(4), 436-445. https://doi.org/10.2307/798843

Glaser, B. G. (1978). Theoretical sensitivity. Advances in the methodology of grounded theory. The Sociology Press.

Glaser, B. G., \& Strauss, A. L. (1967). Grounded theory: Strategies for qualitative research. Aldine Publishing Company. https://doi.org/10.1097/00006199-196807000-00014

Gleason, P., Crissey, S., Chojnacki, G., Zukiewicz, M., Silva, T., Costelloe, S., \& O’Reilly, F. (2019). Evaluation of support for using student data to inform teachers' instruction. NCEE 2019-4008. National Center for Education Evaluation and Regional Assistance. Retrieved from https://ies.ed.gov/ncee/pubs/20194008/

Golberstein, E., Wen, H., \& Miller, B. F. (2020). Coronavirus disease 2019 (COVID-19) and mental health for children and adolescents. JAMA Pediatrics. https://doi.org/10.1001/jamapediatrics.2020.1456

Goodman, R. (1997). The Strengths and Difficulties Questionnaire: A research note. Journal of Child Psychology and Psychiatry, 38, 581-586. https://doi.org/10.1111/j.1469-7610.1997.tb01545.x

Graham, K. (2020, May 14). Who's showing up for school during the pandemic? In Philly, it's just over half of students. Inquirer. Retrieved from https://www.inquirer.com/ 
Guskey, T. R., \& Passaro, P. D. (1994). Teacher efficacy: A study of construct dimensions. American Educational Research Journal, 31(3), 627-643. https://doi.org/10.3102/00028312031003627

Hancock, D. R., \& Algozzine, B. (2017). Doing case study research: A practical guide for beginning researchers. Teachers College Press.

Hattie, J., \& Anderman, E. M. (2019). Visible learning guide to student achievement (schools ed.). Routledge. https://doi.org/10.4324/9781351257848

Haverback, H. R. (2020). Middle level teachers quarantine, teach, and increase self-efficacy beliefs: Using theory to build practice during COVID-19. Middle Grades Review, 6(2), 2. Retrieved from https://scholarworks.uvm.edu/

Heatherton, T. F., \& Polivy, J. (1991). Development and validation of a scale for measuring state self-esteem. Journal of Personality and Social Psychology, 60, 895. https://doi.org/10 .1037/0022-3514.60.6.895

Hirsch, R. A., Dierkhising, C. B., \& Herz, D. C. (2018). Educational risk, recidivism, and service access among youth involved in both the child welfare and juvenile justice systems. Children and Youth Services Review, 85, 72-80. https://doi.org/10.1016/j.childyouth.2017.12.001

Hobbs, T. D., \& Hawkins, L. (2020, June 5). The results are in for remote learning: It didn't work. Wall Street Journal. Retrieved from https://www.wsj.com/

Illinois State Board of Education. (2020). Student attendance during remote learning. Retrieved from https://www.isbe.net/Documents/Student-Attendance-Guidance-5-4-20.pdf

Jacob, B. A., \& Lefgren, L. (2004). Remedial education and student achievement: A regression-discontinuity analysis. Review of Economics and Statistics, 86(1), 226-244. https://doi.org/10.1257/app.1.3.33

Jacobson, L. (2020, May 20). Survey: Children's loss of social ties, learning are parents' top closure concerns. Education Dive. Retrieved from https://www.educationdive.com/

Jaggers, J. W., Robison, S. B., Rhodes, J. L., Guan, X., \& Church, W. T. (2016). Predicting adult criminality among Louisiana's urban youth: Poverty, academic risk, and delinquency. Journal of the Society for Social Work and Research, 7(1), 89-116. https://doi.org/10.1086/685089

Johnson, R. B., Onwuegbuzie, A. J., \& Turner, L. A. (2007). Toward a definition of mixed methods research. Journal of Mixed Methods Research, 1(2), 112-133. https://doi.org/10.1177/1558689806298224

Kaden, U. (2020). COVID-19 school closure-related changes to the professional life of a K-12 teacher. Education Sciences, 10(6), 165. https://doi.org/10.3390/educsci10060165

Kaffenberger, M. (2020). Modeling the long-run learning impact of the COVID-19 learning shock: Actions to (more than) mitigate loss. RISE Insight Series, 17. https://doi.org/10.35489/BSG-RISE-RI_2020/017

Kang, S., Sun, Y., Zhang, X., Sun, F., Wang, B., \& Zhu, W. (2020). Is physical activity associated with mental health among Chinese adolescents during isolation in COVID-19 pandemic? Journal of Epidemiology and Global Health. https://doi.org/10.2991/jegh.k.200908.001

Klein, A. (2019, August 6). 5 big ed-tech problems to solve in 2020: Q\&A with ISTE's Richard Culatta. Education Week's Blog Digital Leadership. Retrieved from http://blogs.edweek.org/

Korman, H. T., O'Keefe, B., \& Repka, M. (2020). Missing in the margins: Estimating the scale of the COVID-19 attendance crisis. Bellwether Education Partners. Retrieved from https://bellwethereducation.org/

Kubek, J. B., Tindall-Biggins, C., Reed, K., Carr, L. E., \& Fenning, P. A. (2020). A systematic literature review of school reentry practices among youth impacted by juvenile justice. Children and Youth Services Review, 110, 104773. https://doi.org/10.1016/j.childyouth.2020.104773

Kuhfeld, M., Soland, J., Tarasawa, B., Johnson, A., Ruzek, E., \& Liu, J. (2020). Projecting the potential impacts of COVID-19 school closures on academic achievement. Annenberg Institute Working Paper, 49(8), 549-565. https://doi.org/10.3102/0013189X20965918

Leech, N. L., \& Onwuegbuzie, A. J. (2009). A typology of mixed methods research designs. Quality \& Quantity, 43(2), 265-275. https://doi.org/10.1007/s11135-007-9105-3

Lindberg, N., Miettunen, J., Heiskala, A., \& Kaltiala-Heino, R. (2017). Mortality of young offenders: A national register-based follow-up study of 15 to 19-year-old Finnish delinquents referred for forensic psychiatric examination between 1980 and 2010. Child and Adolescent Psychiatry and Mental Health, 11(37). 
https://doi.org/10.1186/s13034-017-0174-3

Linder, K. E., \& Hayes, C. M. (Eds.). (2020). High-impact practices in online education: Research and best practices. Stylus Publishing.

Loades, M. E., Chatburn, E., Higson-Sweeney, N., Reynolds, S., Shafran, R., Brigden, A., ... Crawley, E. (2020). Rapid systematic review: The impact of social isolation and loneliness on the mental health of children and adolescents in the context of COVID-19. Journal of the American Academy of Child \& Adolescent Psychiatry, 59(11), 1218-1239. https://doi.org/10.1016/j.jaac.2020.05.009

Lyons, R. F., Mickelson, K. D., Sullivan, M. J., \& Coyne, J. C. (1998). Coping as a communal process. Journal of Social and Personal Relationships, 15(5), 579-605. https://doi.org/10.1177/0265407598155001

MacIntyre, P. D., Gregersen, T., \& Mercer, S. (2020). Language teachers' coping strategies during the Covid-19 conversion to online teaching: Correlations with stress, wellbeing and negative emotions. System, 94. https://doi.org/10.1016/j.system.2020.102352

Malkus, N., \& Christensen, C. (2020). School district responses to the COVID-19 pandemic: Round 4, halfway through closures. American Enterprise Institute. Retrieved from http://www.aei.org

Marsh, H. W. (1990). The structure of academic self-concept: The Marsh/Shavelson model. Journal of Educational Psychology, 82(4), 623. https://doi.org/10.1037/0022-0663.82.4.623

McRae, K., Ciesielski, B., \& Gross, J. J. (2012). Unpacking cognitive reappraisal: Goals, tactics, and outcomes. Emotion, 12(2), 250-255. https://doi.org/10.1037/a0026351

Mills, L. A., Baker, L., Wakefield, J. S., \& Angnakoon, P. (2018). How do high school students prefer to learn? In Digital Technologies: Sustainable Innovations for Improving Teaching and Learning (pp. 95-110). Springer. https://doi.org/10.1007/978-3-319-73417-0_6

Murphy, P. K., Delli, L. A. M., \& Edwards, M. N. (2004). The good teacher and good teaching: Comparing beliefs of second-grade students, preservice teachers, and inservice teachers. The Journal of Experimental Education, 72(2), 69-92. https://doi.org/10.3200/JEXE.72.2.69-92

Neuman, S. B. (2016). Code red: The danger of data-driven instruction. Educational Leadership, 74(3), $24-29$. Retrieved from http://www.ascd.org/publications/educational_leadership/

Noonoo, S. (2020, October 6). 'This job is impossible:' Frustrated teachers share what America's classrooms are really like. Edsurge. Retrieved from https://www.edsurge.com/

Onwuegbuzie, A. J., Frels, R. K., \& Hwang, E. (2016). Mapping Saldaña's coding methods onto the literature review process. Journal of Educational Issues, 2(1), 130-150. https://doi.org/10.5296/jei.v2i1.8931

Onwuegbuzie, A. J., \& Johnson, R. B. (2006). The validity issue in mixed research. Research in the Schools, 13(1), 48-63. Retrieved from http://www.msera.org/publications-rits.html

Onwuegbuzie, A. J., Leech, N. L., \& Collins, K. M. (2012). Qualitative analysis techniques for the review of the literature. Qualitative Report, 17, 56. Retrieved from https://nsuworks.nova.edu/tqr/

Panayiotou, M., Humphrey, N., \& Wigelsworth, M. (2019). An empirical basis for linking social and emotional learning to academic performance. Contemporary Educational Psychology, 56, 193-204. https://doi.org/10.1016/j.cedpsych.2019.01.009

Patton, M. Q. (1999). Enhancing the quality and credibility of qualitative analysis. Health Services Research, 34(5 Pt 2), 1189-1208. Retrieved from https://www.ncbi.nlm.nih.gov/pmc/articles/

Phondej, W., Kittisarn, A., \& Neck, P. (2011). The seven steps of case study development: A strategic qualitative research methodology in female leadership field. Review of International Comparative Management, 12(1), 123-134. Retrieved from https://www.ceeol.com/

Poletti, M. (2020). Hey teachers! Do not leave them kids alone! Envisioning schools during and after the coronavirus (COVID-19) pandemic. Trends in Neuroscience and Education. https://doi.org/10.1016/j.tine.2020.100140

Praetorius, A. K., Klieme, E., Herbert, B., \& Pinger, P. (2018). Generic dimensions of teaching quality: The German framework of three basic dimensions. ZDM, 50(3), 407-426. https://doi.org/10.1007/s11858-018-0918-4

Pyle, N., Flower, A., Williams, J., \& Fall, A. M. (2020). Social risk factors of institutionalized juvenile offenders: A systematic review. Adolescent Research Review, 5(2), 173-186. 
https://doi.org/10.1007/s40894-019-00120-2

Regional Office of Education \#54. (2020). 6-day enrollment history in Vermilion County.

Robins, R. W., Hendin, H. M., \& Trzesniewski, K. H. (2001). Measuring global self-esteem: Construct validation of a single-item measure and the Rosenberg Self-Esteem Scale. Personality and Social Psychology Bulletin, 27(2), 151-161. https://doi.org/10.1177/0146167201272002

Robinson, D., \& Lewis, C. W. (2017). Typologies for effectiveness: Characteristics of effective teachers in urban learning environments. Journal of Urban Learning, Teaching, and Research, 13, 124-134. Retrieved from https://aera-ultr.wixsite.com/ultr

Robles, A., Gjelsvik, A., Hirway, P., Vivier, P. M., \& High, P. (2019). Adverse childhood experiences and protective factors with school engagement. Pediatrics, 144(2). https://doi.org/10.1542/peds.2018-2945

Rozas, L. W., \& Klein, W. C. (2010). The value and purpose of the traditional qualitative literature review. Journal of Evidence-Based Social Work, 7(5), 387-399. https://doi.org/10.1080/15433710903344116

Rundle, A. G., Park, Y., Herbstman, J. B., Kinsey, E. W., \& Wang, Y. C. (2020). COVID - 19-Related school closings and risk of weight gain among children. Obesity. https://doi.org/10.1002/oby.22813

Saldaña, J. (2015). The coding manual for qualitative researchers. Sage.

Sedlak, A., \& Bruce, C. (2016). Survey of youth in residential placement: Youth characteristics and backgrounds. Westat. Retrieved from https://www.ncjrs.gov/

Shukla, K., Konold, T., \& Cornell, D. (2016). Profiles of student perceptions of school climate: Relations with risk behaviors and academic outcomes. American Journal of Community Psychology, 57(3-4), 291-307. https://doi.org/10.1002/ajcp.12044

Silva, N., Pereira, M., Otto, C., Ravens-Sieberer, U., Canavarro, M. C., \& Bullinger, M. (2019). Do 8-to 18-year-old children/adolescents with chronic physical health conditions have worse health-related quality of life than their healthy peers? A meta-analysis of studies using the KIDSCREEN questionnaires. Quality of Life Research, 1-26. https://doi.org/10.1007/s11136-019-02189-7

Strauss, A., \& Corbin, J. M. (1997). Grounded theory in practice. Sage.

Tankersley, K. (2005). Literacy strategies for grades 4-12: Reinforcing the threads of reading. ASCD.

Thurmond, V. A. (2001). The point of triangulation. Journal of Nursing Scholarship, 33(3), 253-258. https://doi.org/10.1111/j.1547-5069.2001.00253.x

Vegas, E., \& Winthrop, R. (2020). Beyond reopening schools: How education can emerge stronger than before COVID-19. Brookings Institute. Retrieved from https://www.brookings.edu

Walters, G. D. (2020). Desistance and identity: Do reflected appraisals as a delinquent impede the crime-reducing effects of the adolescent-to-adult transition? Criminal Justice Review, 45(3), 303-318. https://doi.org/10.1177\%2F0734016819899133

Wexler, N. (2019a). How classroom technology is holding students back. MIT Technology Review. Retrieved from https://www.technologyreview.com/

Wexler, N. (2019b). To help students who are several "grade levels" behind in reading, focus on building-and assessing-students' knowledge. The Fordham Institute Flypaper. Retrieved from https://fordhaminstitute.org/national/commentary/

Yin, R. K. (2018). Case study research and applications: Design and methods (6th ed.). Sage Publications.

\section{Copyrights}

Copyright for this article is retained by the author, with first publication rights granted to the journal.

This is an open-access article distributed under the terms and conditions of the Creative Commons Attribution license (http://creativecommons.org/licenses/by/4.0/). 